\title{
Spatial Analysis of Hydrological Productivity in Fractured Bedrock Terrains of the Piedmont of Northwestern South Carolina
}

\author{
Brooks Bailey ${ }^{1}$, Weston Dripps $^{1 *}$, and Suresh Muthukrishnan ${ }^{1}$
}

AUTHORS: 'Department of Earth and Environmental Sciences, Furman University, Greenville, SC 29613.

*weston.dripps@furman.edu

\begin{abstract}
Fractured bedrock aquifers are structurally complex groundwater systems. Groundwater flow is limited to secondary porosity features such as faults and fractures on account of the low primary porosity and permeability of the native bedrock. The hydrologic productivity of wells drilled within these systems is spatially and vertically variable because of limited interconnectivity among these features. The purpose of this study was to assess potential correlations between driller-estimated well yields and the mapped lithology and structural features of the fractured bedrock aquifers of the Piedmont of northwestern South Carolina. Groundwater well data (e.g., well depth, well yields, static water level) of 1,069 wells, geologic data (e.g., lithology, mapped structural features), and topographic data (e.g., surface elevation, slope) were integrated within a geographic information system database for a spatial analysis of well yield distribution. Wells drilled in alluvium had the highest median yield ( $15 \mathrm{gal} / \mathrm{min})$, whereas those drilled in schist, amphibolite, and gneisses had lower median yields $(9,8.5$, and $8 \mathrm{gal} / \mathrm{min}$, respectively). Nonparametric statistical analyses indicated that no geologic or topographic variables considered were strongly or moderately correlated with reported well yields. Spearman's correlation coefficients for well depth (0.24), static water level (0.19), proximity to water bodies $(-0.10)$, and proximity to lithologic contacts $(-0.08)$ were statistically significant (at the 0.05 confidence level) but only weakly correlated with well yield. Topographic variables and proximity to mapped faults were not statistically significant. Wells drilled in alluvium had the highest yields due to the higher porosity and permeability compared to the bedrock. However, alluvium makes up less than 5\% of the study area surface, and so opportunities to further tap this unit are limited and spatially constrained. The lower median yields of other lithologies are attributed to the lack of fracture development in amphibolite and the low degree of weathering within gneiss foliation planes. To maximize yields, wells should be drilled in alluvium close to water bodies and lithologic contacts where possible.
\end{abstract}

\section{INTRODUCTION}

Understanding the hydrology of fractured rock terrains remains one of the most challenging and complex problems in water resources management and development. The challenges stem from the inherent structural complexities of aquifers in fractured crystalline bedrock (Moore et al., 2002). Bedrock is typically characterized by low matrix permeability and porosity with flow largely governed by secondary porosity features such as fractures and faults (Boutt et al., 2010). Water availability in fractured rock terrains is spatially and vertically variable and can range over several orders of magnitude among lithologies and over relatively short distances due to heterogeneous fracture distribution and variable degrees of interconnectivity between structural features (Shapiro et al., 1999). The Piedmont of northwestern South Carolina is a structurally complex, fractured igneous and metamorphic rock terrain with geology that has been surficially studied and mapped over the past 4 decades (Garihan, 2009; Garihan et al., 2005; Gellici, 1989; Griffin, 1974; Mitchell, 1995; Shapiro et al., 1999). During this same time period, there has been a proliferation of groundwater wells drilled in the regional fractured crystalline bedrock for domestic, agricultural, and municipal use (Gellici, 1989), but no previous attempts have been made to relate the observed structural features and lithological units to the subsurface hydrology of the region. With increasing demand for water resources, there is a greater need for understanding the relationship between the region's geology and hydrological productivity (Wachob et al., 2009). Identifying the structural and geological features associated with hydrologically productive areas will aid groundwater prospecting efforts and promote sustainable development of groundwater resources in fractured bedrock aquifers in this region and other fractured bedrock terrains. 


\section{Bailey, Dripps, Muthukrishnan}

Many previous researchers have attempted to identify and characterize hydrologically productive zones in fractured bedrock terrains in response to the increasing importance of fractured bedrock aquifers as a water source, particularly for rural populations in places where surface flow does not meet water demands (Henriksen, 1995; Mabee, 1999; Moore et al., 2002; Yin \& Brook, 1992). These studies have shown that the factors controlling hydrologic productivity are numerous and vary by physiographic and geologic setting. Henriksen (1995) examined the relationship between topography and well yield in the crystalline bedrock of western Norway and found that boreholes drilled in flatlands and valley bottoms have significantly higher yields than those in fjords and valley slopes, presumably due to lower recharge rates associated with steeper topographic settings. Conversely, Yin and Brook (1992) observed no significant relationship between surface topography and hydrologic productivity in the Blue Ridge physiographic province of northeastern Georgia, but found that well depth and proximity to fracture traces had the greatest influence on well yield. Other studies (Edet et al., 1998; Magowe \& Carr, 1999; Solomon \& Quiel, 2006) have focused on the relationship between fracture traces and well yield. Water prospecting efforts in the crystalline bedrock settings of northeast, south, and central Africa have shown that high well yield is associated with proximity to fracture traces (Edet et al., 1998; Magowe \& Carr, 1999; Solomon \& Quiel, 2006). Moore et al. (2002) found a relationship between well yield and a number of factors including topographic slope and proximity to surface water bodies within the glaciated metamorphic terrain of New Hampshire. Mabee (1999) analyzed several variables in a study of hydrologic productivity in glaciated metamorphic bedrock of Maine and found a moderate positive relationship between bedrock type and structural position with well yield. Wells drilled in amphibolite near anticline limbs had the highest reported yields (Mabee, 1999). These studies, from various similar geological terrains and physiographic settings, highlight that the controlling factors of well yield appear to be variable and, in places, spatially dependent on a variety of structural, lithologic, and topographic features.

The fractured crystalline bedrock terrain of the Piedmont and Blue Ridge provinces of the Carolinas has been the focus of much previous geological and hydrological research. Daniel (1989) related well construction methods to well yield in western North Carolina and found that high yields were associated with deeper wells. There was a considerable scatter in yields for wells drilled in generalized geologic belts including the Blue Ridge, Chauga, Carolina Slate, and Charlotte belts. The Piedmont of South Carolina has been surficially studied and mapped on 1:24,000 topographic quadrangles. Mitchell (1995) conducted a survey of groundwater wells of Greenville County in conjunction with the South Carolina Department of Natural Resources, which provided a descriptive statistical, but not spatial, assessment of well productivity within the county. Snipes et al. (1983) examined the relationship between well yield and lithological unit with Abbeville County of northwestern South Carolina and found that regions with fractured rocks were more hydrologically productive than those without fractures. However, little work has been done to relate the mapped structural and geological features with the hydrology of the Piedmont, and to date, the controls of hydrologic productivity in the region remain largely unknown.

The purpose of this study was to assess potential correlations between driller estimated well yields and the mapped lithology and structural features of the fractured bedrock aquifers of the Piedmont of northwestern South Carolina. Results could be used to characterize hydrologically productive areas within the Piedmont of South Carolina based on their respective structural and geologic settings. Groundwater well data and geologic data were combined to explore potential controls of hydrologic productivity in the fractured bedrock of South Carolina and thereby improve our knowledge of complex fractured bedrock aquifers in other regions. Collectively, the work is intended to lead to better groundwater prospecting methodology and improved management strategies for these important water resources.

\section{STUDY AREA}

The area investigated covers approximately $2,450 \mathrm{~km}^{2}$ in the Piedmont region of northwestern South Carolina, defined by 15 U.S. Geological Survey 1:24,000-scale topographic quadrangles, and includes portions of northeastern Pickens County, northern Greenville County, and northwestern Spartanburg County (Figure 1). The study area spans from the gently rolling to hilly topography of the Piedmont physiographic province to the more rugged mountains and narrow valleys of the Blue Ridge physiographic province, with elevations ranging from $240 \mathrm{~m}$ to $900 \mathrm{~m}$ above sea level. The region has a humid subtropical climate, with warm to hot summers with daytime highs around $32^{\circ} \mathrm{C}$ and cold to mild winters with highs typically $5-10^{\circ} \mathrm{C}$. Average annual precipitation varies across the Piedmont from 180 to 115 $\mathrm{cm}$, decreasing from northwest to southeast largely due to the orographic effect of the Appalachian Mountain front (Cherry et al., 2001). Temporal precipitation distribution is relatively even across the year. During the summer, the main sources of rainfall are occasional tropical storms and regular afternoon thunderstorms produced by convective heating. During the winter, precipitation is primarily due to extratropical cyclones. Estimated annual recharge (precipitation-evapotranspiration) follows a similar spatial pattern to precipitation ranging from $100 \mathrm{~cm}$ to $40 \mathrm{~cm}$ from the mountains to the state's interior (Cherry et al., 2001). 


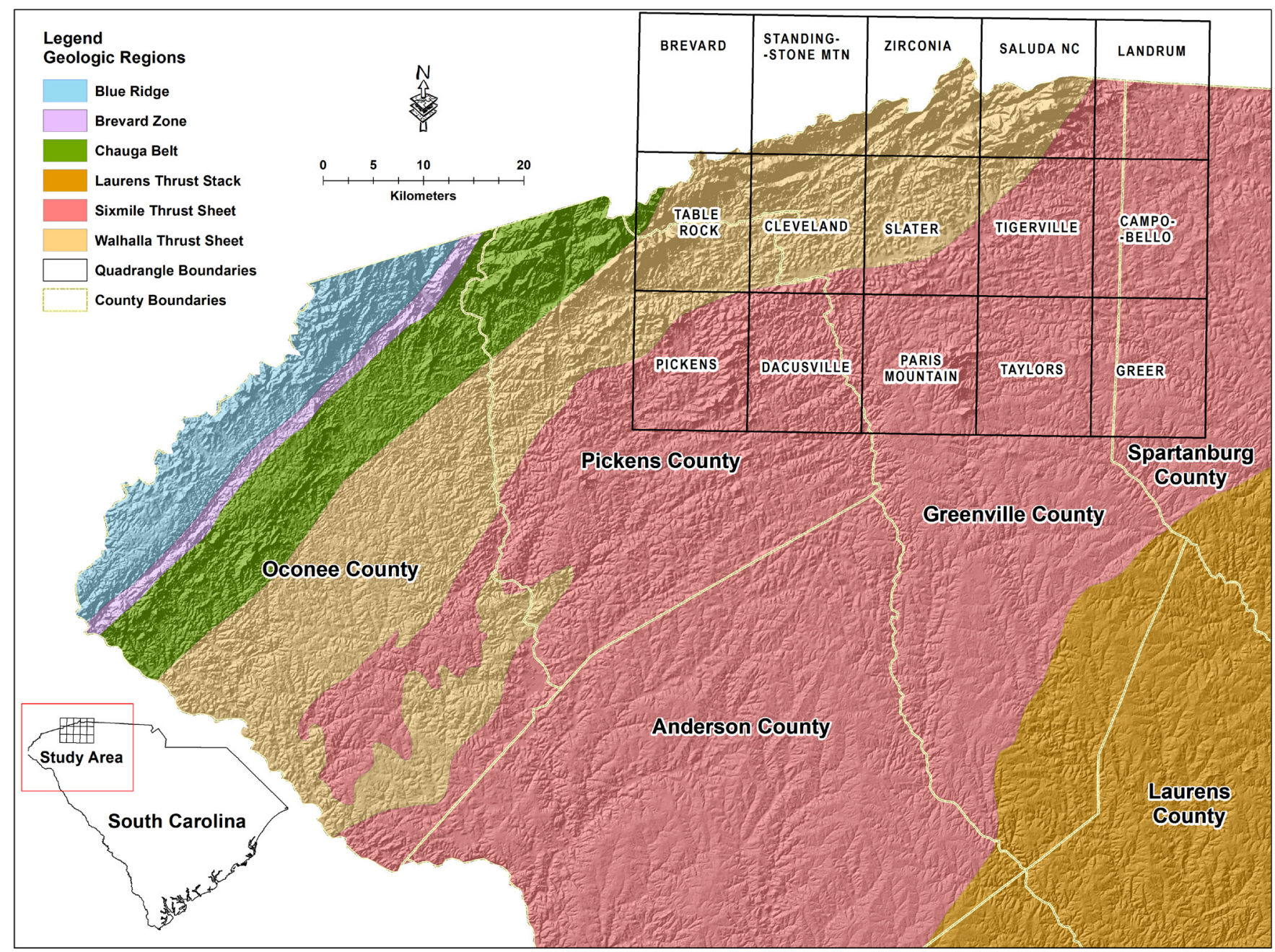

Figure 1. Study area composed of 15 topographic quadrangles in northwestern South Carolina. Major geologic regions are marked.

Geologically, the study area is located entirely within the inner belt of the Piedmont province (Willoughby et al., 2005). The prominent macroscopic structural features in the study area consist of the Six Mile and overlying Walhalla thrust sheet, a pair of westward-thrusting nappes trending northeast-southwest (Griffin, 1974). Other structural features include thrust faults, slip faults, synclines, anticlines, and diabase dikes. The majority of faults trend northeastsouthwest, with dikes trending southwest-northeast. The underlying geology features a suite of metamorphic and igneous rocks with a metamorphic grade falling within the sillimanite zone of the amphibolite facies (Hatcher, 2002). The 4 main lithological map units include Poor Mountain Formation amphibolite (PMa; a well-foliated, slabby, fine- to medium-crystalline rock); Tallulah Falls Formation (TF; a mix of migmatitic and micaceous gneiss and schist); Table Rock gneiss (TRg; a biotite-rich quartzofeldspathic gneiss); and Quaternary alluvium (Qal; gravel, sand, silt, and clay deposits; Garihan et al., 2005; Figures 1 and 2).

The hydrology within the study area is controlled by a simplified, dual aquifer system consisting of regolith and fractured bedrock (Mitchell, 1995). The weathered regolith material overlying the bedrock, also known as saprolite, ranges in thickness from $3 \mathrm{~m}$ to $30 \mathrm{~m}$ (LeGrand, 1989). The saprolite zone is characterized by low permeability and high porosity and thus functions as a reservoir that feeds water into fractures within the underlying bedrock (LeGrand, 1989). Although the water storage capacity of fractured bedrock is low, water is capable of being transmitted along fractures and fracture intersections within the bedrock (Heath, 1980). The ability of these fractures to hold and transmit water diminishes with depth and tends to cease below about $30 \mathrm{~m}$ due to lithostatic pressure (Daniel, 1989).

\section{METHODS}

This study integrates lithologic, structural, and hydrologic data in an attempt to better identify the controls on the complex fractured bedrock hydrology of the South Carolina Piedmont region. The data used came from a number of different sources and were compiled into ArcGIS software for spatial and statistical analyses. 


\section{Bailey, Dripps, Muthukrishnan}

Scale 1:24000 digital geological data were obtained for the study from the South Carolina Geologic Survey. The data were in digital Geographic Information System (GIS)ready format for the 15 topographic quadrangles that cover the study area (Figure 1) and included many of the mapped surface features such as lithology, faults, tectonic folds, diabase dikes, brecciated rock zones, and water bodies. To perform the spatial analysis of well yield by lithology, the 43 reported mapped lithologic units from the original data were combined into 4 main lithologic groups including gneiss (TRg and TF subunits), amphibolite (PMa subunits), schist (TFs subunits and other micaceous schists), and alluvium (Qal) (Figure 2). Because structural features within the digital maps were organized as a mass of interconnected polyline features, individually mapped structural features were manually selected and extracted as separate, distinct shapefile feature classes to facilitate spatial analysis of well yield. The well data for the study area-which includes well depth, intended water use, estimated well yield, well log, drilling method, casing type, casing diameter, depth to bottom of casing, and static water level for each well-were obtained from South Carolina Department of Natural Resources.
Data are available, with varying degrees of precision for the 25,054 wells in 17 counties across the Piedmont of South Carolina. Only wells with localities that were known to the nearest second within the study area were selected. In all, this resulted in 1,069 wells that were imported into GIS and included in the study (Figure 2).

The state digital elevation model was obtained from the USGS at 1:250,000 with a cell size of $30 \times 30 \mathrm{~m}$. Topographic concavity and slope indices were extracted using the ArcGIS tools. Values for these data were extracted for each individual well locality to characterize the topographic setting for each well within the study area. The Near tool in ArcGIS was used to calculate straight-line distances (in meters) from wells to structural features within the quadrangle maps of the study area. Both water body density and fault density data were generated using the Line Density tool, which was used to calculate the density of faults and water body features within a circle with an area of $1 \mathrm{~km}^{2}$ around each raster cell center. The goal in creating these thematic maps was to quantify the concentration of water bodies and fault zones, with the assumption that areas with a higher concentration of these features would be more hydrologically productive than those

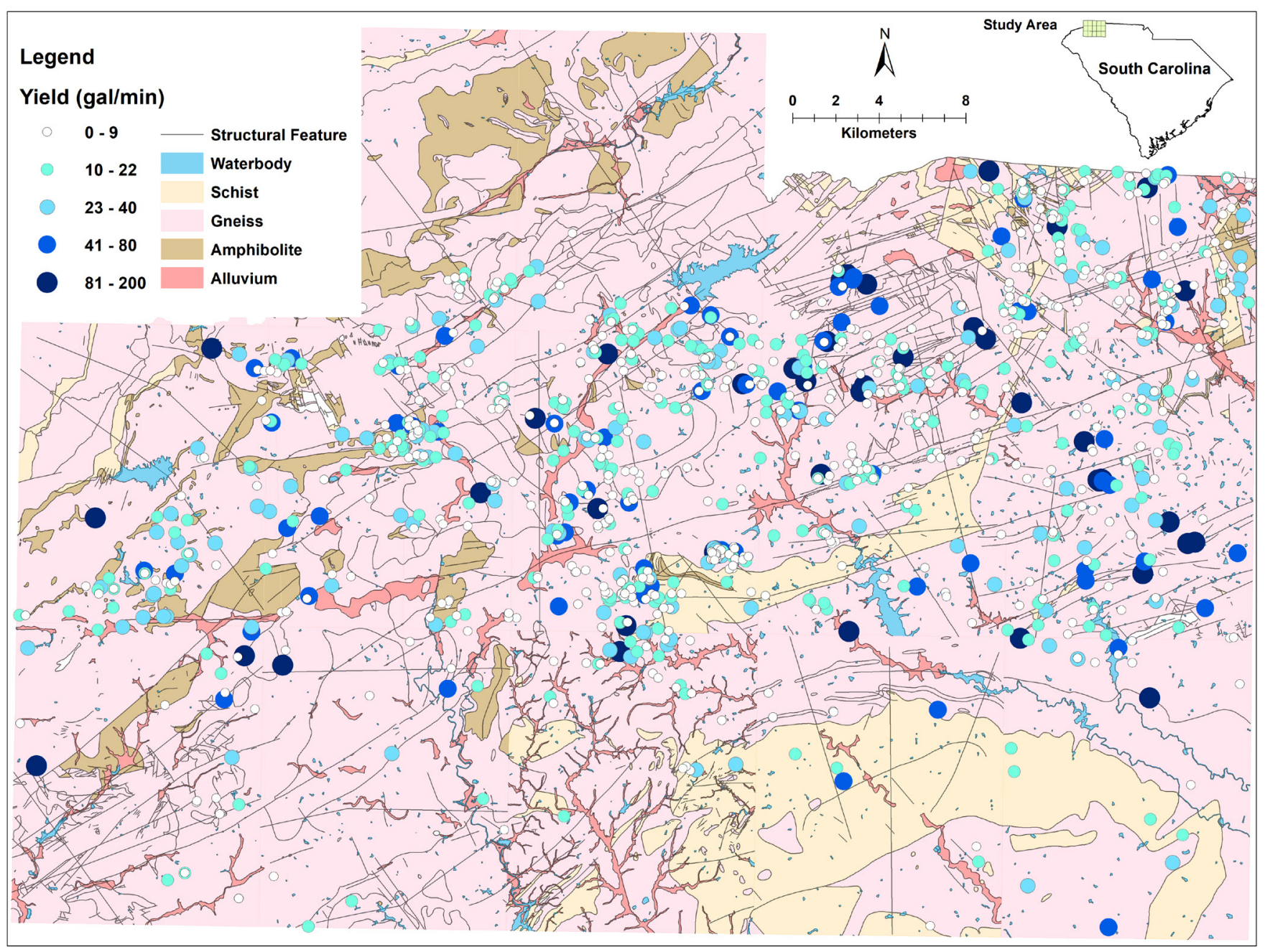

Figure 2. Generalized lithology, mapped structural features, and spatial distribution of well yields within study area. 


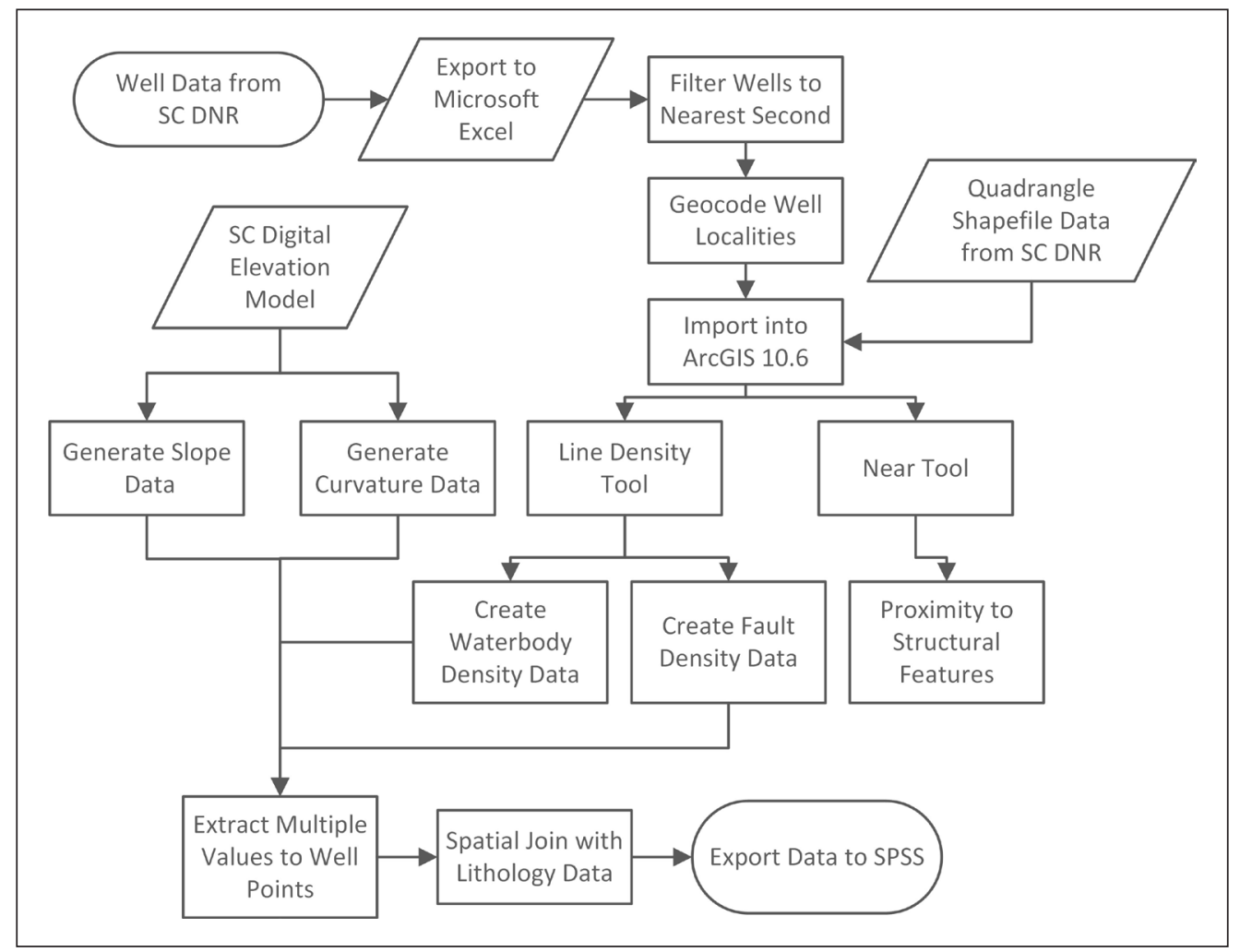

Figure 3. Workflow chart of procedures executed in ArcGIS.

with lower concentrations. The results of spatial analyses were then exported for statistical analysis (Figure 3).

\section{STATISTICAL TESTS}

Statistical tests were performed on the well data using SPSS Version 20.0 (IBM Corp., 2011) to determine quantitative relationships between hydrological and geological factors. Driller-reported well yield (in gallons per minute) was used to represent each site's hydrological productivity. The Shapiro-Wilks test was used to assess the well yield data distribution. The null hypothesis of normal distribution was disproved $(P<0.05)$, indicating that the data were nonnormally distributed. The same procedure was repeated for natural-log-transformed data and yielded the same result. Because parametric statistical methods require normal distribution of data, the nonnormal, nonparametric statistical methods were used to check correlations within the positively skewed, nonnormal well yield data. Unlike parametric statistical methods, which test the differences in the means of data, nonparametric methods test the differences in the medians of data. Thus, nonparametric methods have less predictive power than parametric methods, but nonparametric methods still calculate direct correlations within data. Well yield was compared with both categorical and continuous data from the database, including well parameters (well depth, depth of casing, and static water level); well proximity to surface water bodies, topographic features (slope), lithologic features (contacts and diabase dikes), structural features (synform axes, antiform axes, breccia zones, thrust faults, slip faults, and all faults); and density of water body and fault.

The Spearman's $\rho$ rank correlation coefficient method was used to calculate correlations between well yield and other continuous variables within the database at the 0.05 significance level. To ensure correlation accuracy, continuous data including straight-line distances to mapped structural features were reclassified into groups of ordinal variables according to the methods of Moore et al. (2002). The Wilcoxon test was used to identify any significant differences in yield for wells grouped by simplified lithological units, following the methods of Henriksen (1995).

\section{RESULTS}

\section{STATISTICAL AND SPATIAL ANALYSES OF WELL YIELD}

Summary statistics for wells grouped according to lithology are shown in Tables 1 and 2. Wells drilled in alluvium have the highest mean and median yield. Median well yield is similar between schist, amphibolites, and undifferentiated gneisses. The number of wells drilled in gneisses is nearly 2 orders of magnitude higher than those in the other three lithologic units. Results of the Wilcoxon test show that differences in well yield between lithologically grouped samples are only statistically significant at the 0.05 confidence level between schist and alluvium. 
Table 1. Summary statistics for wells grouped according to generalized surface lithology at drill site (Min. = minimum; Max. = maximum; total wells, $n=1,069 ; \mathrm{UG}=$ undifferentiated gneisses; $\mathrm{Am}=$ amphibolite; $\mathrm{S}=$ schist; $\mathrm{Al}=$ alluvium).

\begin{tabular}{lcccc}
\hline & UG & Am & S & Al \\
\hline Wells, $n$ & 956 & 36 & 58 & 19 \\
Min. yield, gpm & 0 & 2 & 0 & 1 \\
Max. yield, gpm & 200 & 50 & 50 & 45 \\
Median & 8 & 8.5 & 9 & 15 \\
Mean, gpm & 18.56 & 13.14 & 12.28 & 19.53 \\
SD, gpm & 27.83 & 12.23 & 12.73 & 14.47 \\
\hline
\end{tabular}

Table 2. Data matrix for generalized lithology $(Y=$ significant and $\mathrm{N}=$ no significant difference between a pair of lithologically grouped samples according to the Wilcoxon test at the 0.05 confidence level; total wells, $n=1,069$. UG = undifferentiated gneisses; $\mathrm{Am}=$ amphibolite; $\mathrm{S}=$ schist; $\mathrm{Al}=$ alluvium).

\begin{tabular}{lcccc}
\hline & UG & Am & S & Al \\
\hline UG & - & & & \\
Am & N & - & & \\
S & N & N & - & \\
$\mathrm{Al}$ & $\mathrm{N}$ & $\mathrm{N}$ & $\mathrm{Y}$ & - \\
\hline
\end{tabular}

Results of the Spearman's $\rho$ correlation (Table 3) indicate that well depth, static water level, and proximity to surface water bodies and lithological contacts are the only statistically significant variables related to well yield. Despite their significance, these variables are only weakly correlated with changes in well yield. Of the variables considered, well depth is the highest correlated to well yield, with deeper wells associated with higher yields. Static water level elevation is the second highest correlated variable related to well yield, with higher static water level related to higher well yield. Well proximity to surface water bodies and lithological contacts are also weakly - very weakly_correlated to well yield. Wells closer to these features are associated with higher yields, as indicated by the negative Spearman $\rho$ coefficients.

\section{DISCUSSION}

The fractured bedrock aquifer of the Piedmont of northwestern South Carolina presents a hydrological challenge. Little is known regarding the structural, topographic, or lithological controls of hydrological productivity in the region. Whereas previous studies (Daniel, 1989; Gellici, 1989; Mitchell, 1995) provided descriptive statistical assessments of hydrological productivity, this study attempted to reveal the spatial relationships between the driller-estimated well yields and the mapped lithology and structural features of the region.
Table 3. Results of Spearman's $\rho$ correlation of well yield with continuous variables ("significant at the 0.05 confidence level).

\begin{tabular}{lcc}
\hline Variable & Spearman's $\boldsymbol{\rho}$ & $\mathbf{P}$ \\
\hline Well depth & 0.2433 & $<0.0001^{*}$ \\
Static water level & 0.1925 & $<0.0001^{*}$ \\
Slope & -0.0449 & 0.142 \\
Depth of casing & -0.0412 & 0.1785 \\
Curvature & -0.0345 & 0.2601 \\
Water body density & -0.0135 & 0.6595 \\
Fault density & -0.0086 & 0.7784 \\
Proximity to & & \\
$\quad$ Surface water body & -0.1018 & $0.0009^{*}$ \\
$\quad$ Contacts & -0.0786 & $0.0101^{*}$ \\
$\quad$ Synforms & 0.0383 & 0.2106 \\
$\quad$ Antiforms & 0.0383 & 0.2106 \\
Breccia zone & -0.0281 & 0.359 \\
Thrust faults & 0.037 & 0.2264 \\
Slip faults & -0.0113 & 0.7121 \\
All faults & 0.0169 & 0.5813 \\
Diabase dikes & 0.0024 & 0.9385 \\
\hline
\end{tabular}

The high median yield of wells drilled in alluvium in this study was expected due to the high porosity and permeability of this rock type (Solomon \& Quiel, 2006). However, alluvium makes up less than $5 \%$ of the study area surface (Figure 2), and so opportunities to further tap this unit will likely be limited and constrained spatially. The disparity between the observed mean (higher) and median (lower) yield values for undifferentiated gneisses is most likely due to the larger sample size $(n=956)$ and higher number of high-yield water supply wells drilled in this lithologic unit. Gneisses have shown sizable variability in well yield in several other studies due to composition, weathering, and expression of structural features (Chapman et al., 1999; Snipes et al., 1983; Solomon \& Quiel, 2006). Solomon and Quiel identified foliation planes as permeability-enhancing structures within the gneisses of the central highlands of Eritrea. Chapman et al. (1999) also noted the enhanced weathering potential within the compositional layering of gneisses as a means of enhancing permeability and promoting greater groundwater flow. Biotite gneisses within their study area had the highest yields. Conversely, Snipes et al. (1983) found significantly lower yields within the granitic gneisses of South Carolina. Their reasoning behind the observed low productivities of this unit is attributed to its more massive composition, therefore making it more resistant to weathering. Based on the literature (Chapman et al., 1999; Mabee, 1999), the similarity in median and mean yield for wells drilled in amphibolites and schist (Table 1) 
was unexpected due to the greater degree of fracturing and greater fracture development typically associated with amphibolite units. Mabee (1999) observed greater fracture development and prevalence of steeply dipping, orthogonal fracture networks within the amphibolites of Maine, which he interpreted as the main reason for higher yields in wells drilled in this rock type than those drilled in schists. Chapman et al. (1999) observed prevalent jointing at depth within the amphibolites in upstate Georgia. According to their study, productive fracture zones exist at the intersection of low-angle compositional layering and joint surfaces, along which differential weathering enhances rock permeability. Both studies by Chapman et al. (1999) and Snipes et al. (1983) reported schists to be the least productive rock units within their respective studies. Chapman et al. (1999) identified low weathering potential and lack of jointing as possible reasons for the observed low yields within schist. The amphibolite rock units in this study have a similar fracture network to the schists (Figure 2) and do not appear to have as many well-developed fracture networks as those observed in other studies (Mabee, 1999; Moore et al., 2002; Solomon \& Quiel, 2006). The observed homogeneity between yield values for wells drilled in undifferentiated gneisses, amphibolite, and schist contrasts with the results found by Daniel (1989) in his statistical study of well yield within the Piedmont of North Carolina. He found large variability between yields for wells drilled in various igneous and metamorphic rock units.

Well depth has the strongest relationship, albeit still a very low correlation, with well yield of the 16 variables of the study. This result is consistent with the findings of Moore et al. (2002) and Gellici (1989), who both found significant correlations between increasing well yield with greater well depth within the fractured bedrock aquifers of Maine and the Piedmont of South Carolina, respectively. Gellici noted that the hydrological productivity of deep wells is due in part to the prevalence of continuous, interconnected water-bearing fractures at depth.

In this study, static water level and proximity to surface water bodies were both significantly correlated with well yield. Presumably, these correlations are due to the greater prevalence of groundwater in wells with high static water levels and those proximal to water bodies. Mabee (1999) found no significant correlation between static water level and well yield, but did not offer any explanations for this result. Moore et al. (2002) found a significant inverse correlation between proximity to surface water bodies and well yield.

Proximity to lithological contacts had the weakest statistically significant correlation with well yield of all the variables. It is possible that the contact zones between lithological units within the study area are more transmissive due to the faults that sometimes occur along these contacts. Moore et al. (2002) noted that yield for wells drilled near fracture zones can change based on the lithological contacts crossed by the fracture zone. Moore et al. (2002) mentioned that wells situated near weathered, unconsolidated granitic rocks between unweathered plutonic rock units can have higher yields. Snipes et al. (1983) noted an increase in well yields along wells drilled near lithological contacts, especially contacts near the shattered country rock associated with zones of brecciation. Broken, fragmented brecciated zones should have higher secondary porosity and permeability compared to the bedrock, and as such, it should be more conducive to higher well yields.

Neither of the topographic variables, slope or curvature, was statistically correlated to well yield. Topographic variables were shown to be statistically significant in the fjords of Norway by Henriksen (1995), with higher yielding wells associated with valley bottoms and flatlands, presumably due to greater infiltration and recharge rates in these areas compared with slopes and peaks. Moore et al. (2002) also found a statistically significant relationship between slope and curvature, with high-angle slopes and concave-down regions associated with lower yields. However, Yin and Brook (1992) found no such relationship between well yield and topographic variables within the fractured bedrock terrain of the Georgia Piedmont, with topography explaining a mere $0.1 \%$ of variability in well yield. The topography of the Piedmont of Georgia is more similar to that of South Carolina than the topography found in other study areas, which seems to support the observed lack of correlation between topographic variables and well yield within the Inner Piedmont of South Carolina.

None of the structural features displayed a statistically significant correlation with well yield. Proximity to synforms and antiforms were not correlated with well yield. Mabee (1999) showed that wells located close to fold limbs generally had higher yields. However, he also mentioned that geological unit may have a greater control on well yield than proximity to fold limbs because wells near fold limbs within schist had lower yields than those located in the same structural position within amphibolites. Snipes et al. (1983) noted that structural features including synform axes were linked with increased well yield and explained that these structural features are commonly located along ridges, where the steep dips of the compositional bedding planes facilitate water movement, thus enhancing well productivity. In their study of the regionally folded and deformed fractured bedrock aquifer near the Lawrenceville, Georgia, area, Chapman et al. (1999) found a trend of increasing hydrological productivity for wells situated proximally to antiform axes. They proposed that the regional tectonic stresses that induced folding led to vertical joint development. These highly productive vertical joints are commonly located on or near the hinges of antiformal folds. It is surprising, then, that this study shows no relationship between well yield and proximity to fold features, given the observed positive 


\section{Bailey, Dripps, Muthukrishnan}

trends found in other studies conducted in similar geologic regions. Likewise, proximity to zones of microbreccia was not correlated with well yield. This unconsolidated mass of coarse, angular rocks in a relatively finer grained matrix forms as a result of brittle deformation within a shear zone (Garihan, 2009). It is possible that the fractures associated with this shear zone do not reach the saprolitic regolith and are thus not transmissive. Proximity to diabase dikes was also not correlated with well yield. Although this rock type is characterized by low permeability and is often an aquitard, Chapman et al. (1999) noted that differential weathering between diabase dikes and the surrounding country rock can often result in the formation of preferential flow paths within the bedrock. It seems that if differential weathering has occurred in a similar manner within the study area for this study, then it has not produced any such flow paths within the bedrock. It is surprising that proximity to faults (thrust faults, synform, and antiform) and fault density were not correlated with well yield. Many previous studies (Edet et al., 1998; Mabee, 1999; Magowe \& Carr, 1999; Moore et al., 2002; Solomon \& Quiel, 2006) have consistently demonstrated that wells closer to faults and fracture zones are characterized by higher yields. There are several potential explanations for the lack of association in this study. It is possible that the fracture zones within the aquifer terminate prior to reaching the saprolite aquifer and thus do not transmit water (Mitchell, 1995). Another potential explanation for this trend is that the intense regional compression during emplacement of the nappes resulted in fracture zones with low degrees of interconnectivity and correspondingly low transmissivity.

There are several sources of error that may have influenced the results of this study. Driller-reported well yield is typically estimated on sight by drillers and is thus not always accurate or reliable. These estimates are made by forcing formation water out of the borehole via air pressure and then measuring the subsequent flow of this fluid over a short time interval. Pumping tests provide more accurate, long-term estimates of well yield, but driller-reported yield is favored by drilling companies in the interest of saving time and money (Mitchell, 1995). Thus, well yield can only be treated as a semiquantitative variable, which may distort the results of this study. Another potential source of error pointed out by other authors (Gellici, 1989; Mitchell, 1995; Moore et al., 2002) is that domestic wells are drilled based on the location of the owner's property and the economic constraints of the owner. Wells are not always drilled with the intention of achieving maximum yield; they are often drilled based on the needs of the owner, with the exception of water supply wells that often have higher yields because they are built to achieve maximum groundwater productivity. Because the majority of wells in this study were drilled in undifferentiated gneisses, sample size may be a source of error. Finally, error may also be present in using surface lithology as an indicator of well yield, because some of the deeper wells may tap rock units that are not expressed at the surface. This is a very likely source of error given that Chapman et al. (1999) observed vertical changes in lithology with depth due to intense folding and faulting in regionally deformed crystalline rock terrains.

\section{CONCLUSIONS}

Although the correlations were weak $(|r|<0.25)$, the primary factors impacting hydrological productivity in the Piedmont of South Carolina based on driller-estimated well yields are well depth, static water level, and proximity to surface water bodies and lithological contacts. Similar to Yin and Brook's (1992) study, this article suggests that topography is not a driver of hydrological productivity in the Piedmont of South Carolina. Groundwater prospectors in this and similar regions should target alluvium units proximal to surface water bodies to maximize yields. Within gneisses, prospectors should target the transmissive fractures that seem to exist at depth. This article provides further evidence that fractured bedrock aquifers are among the most difficult water resources to characterize. As Mabee (1999) and Moore et al. (2002) pointed out, there is no universal driver for hydrological productivity in fractured bedrock terrains, and more research and field work are needed to enhance our understanding of these important groundwater resources.

\section{LITERATURE CITED}

Bailey B, Dripps W, Muthukrishnan S. 2013. Spatial analysis of well yields in fractured bedrock terrains of the Piedmont of Northwestern South Carolina. Poster session presented at: Geological Society of AmericaSoutheastern Section 62nd Annual Meeting; San Juan, Puerto Rico.

Boutt DF, Diggins P, Mabee S. 2010. A field study

(Massachusetts, USA) of the factors controlling the depth of groundwater flow systems in crystalline fractured-rock terrain. Hydrogeol J. 18:1839-1854.

Chapman MJ, Crawford TJ, Tharpe WT. 1999. Geology and ground-water resources of the Lawrenceville area, Georgia (Water-Resources Investigations Report 984233). Atlanta (GA): U.S. Geological Survey.

Cherry R, Badr A, Wachob A. 2001. General hydrology of South Carolina. Columbia (SC): South Carolina Department of Natural Resources. http://www.dnr.sc.gov/water/ hydro/HydroPubs/pdf/Map\%202\%20letter\%20size.pdf.

Daniel CC. 1989. Statistical analysis relating well yield to construction practices and siting of wells in the Piedmont and Blue Ridge provinces of North Carolina (Water-Supply Paper 2341). Columbia (SC): South Carolina Department of Natural Resources. 
Edet AE, Okereke CS, Teme SC, Esu EO. 1998. Application of remote-sensing to groundwater exploration: a case study of the Cross River State, southeastern Nigeria: Hydrogeol J. 6:304-404.

Garihan JM, Kalbas JL, Clendenin CW Jr. 2005. Geologic map of the Slater 7.5-minute quadrange, Greenville, County, South Carolina (South Carolina Geological Survey GQM-34). Columbia (SC): South Carolina Department of Natural Resources.

Garihan JM. 2009. Geologic map of the Landrum quadrangle, Greenville and Spartanburg Counties, South Carolina and Polk County, North Carolina (South Carolina Geological Survey GQM-44). Columbia (SC): South Carolina Department of Natural Resources.

Gellici JA. 1989. Borehole geophysics in the Piedmont of South Carolina. In: Daniel CC III, White RK, Stone PA, editors. Ground water in the Piedmont: proceedings of a conference on ground water in the Piedmont of the Eastern United States. Clemson (SC): Clemson University. p. $510-525$.

Griffin VS Jr. 1974. Analysis of the Piedmont in northwest South Carolina. GSA Bull. 85(7):1123-1138.

Hatcher RD Jr. 2002. An Inner Piedmont primer. In: Hatcher RD Jr, Bream BR, editors. Inner Piedmont tectonics focused mostly on detailed studies in the South Mountains and the southern Brushy Mountains, North Carolina: Carolina Geological Society guidebook. Raleigh (NC): North Carolina Geological Survey. p. 1-18.

Heath RC. 1980. Basic elements of ground-water hydrology with reference to conditions in North Carolina (WaterResources Investigations Open-File Report 80-44). Denver (CO): U.S. Geological Survey.

Henriksen H. 1995. Relation between topography and well yield in boreholes in crystalline rocks, Sogn og Fjordane, Norway. Groundw. 33(4):635-643.

IBM Corp. 2011. SPSS Statistics for Windows, version 20.0. Armonk (NY): Author.

LeGrand HE. 1989. A conceptual model of ground water settings in the Piedmont region. In: Daniel CC III, White RK, Stone PA, editors. Ground water in the Piedmont: proceedings of a conference on ground water in the Piedmont of the Eastern United States. Clemson (SC): Clemson University. p. 317-327.

Mabee SB. 1999. Factors influencing well productivity in glaciated metamorphic rocks. Groundw. 37(1):88-97.

Magowe M, Carr JR. 1999. Relationship between lineaments and ground water occurrence in western Botswana. Groundw. 37(2):282-286.

Mitchell HL. 1995. Geology, ground water, and wells of Greenville County, South Carolina (Hydrology-Water Resources Report 8). Columbia (SC): South Carolina Department of Natural Resources.

Moore RM, Schwarz GE, Clark SF Jr, Walsh GJ, Degnan JR. 2002. Factors related to well yield in the fracturedbedrock aquifer of New Hampshire (Professional Paper 1660). Denver (CO): U.S. Geological Survey.
Shapiro AM, Hsieh PA, Haeni GP. 1999. Integrating multidisciplinary investigations in the characterization of fractured rock. In: Morganwalp DW, Buxton HT, editors. U.S. Geological Survey Toxic Substances Hydrology Program: proceedings of the technical meeting-volume 3 of 3: subsurface contamination from point sources (Water Resources Investigations Report 99-4018C). Denver (CO): U.S. Geological Survey. p. 660-680.

Snipes DS, Padgett GG, Hughes WB, Springston GE. 1983. Ground water quantity and quality in fracture zones in Abbeville County, South Carolina (Technical Report no. 102). Clemson (SC): Clemson University Water Resources Research Institute.

Solomon S, Quiel F. 2006. Groundwater study using remote sensing and geographic information systems (GIS) in the central highlands of Eritrea. Hydrogeol J. 14:729-741. doi:10.1007/s10040-005-0477-y.

Wachob A, Park AD, Newcome R Jr. 2009. South Carolina state water assessment. 2nd ed. Columbia (SC): South Carolina Department of Natural Resources.

Willoughby RH, Howard CS, Nystrom PG. 2005. Generalized geologic map of South Carolina. http:// www.dnr.sc.gov/geology/images/GGMS-1\%20Poster\%20 x1 2011.pdf.

Yin Z-Y, Brook GA. 1992. The topographic approach to locating high-yield wells in crystalline rocks: Does it work? Groundw. 30(1):96-102. 